\title{
Accent mark and visual word recognition in Spanish
}

\author{
Sandra Schwab \\ Universität Zürich / Université de Genève \\ Sandra.Schwab@unige.ch
}

Submitted: 15/09/2014. Accepted: 12/12/2014. Available on line: 11/12/2015

Citation / Cómo citar este artículo: Schwab, S. Accent mark and visual word recognition in Spanish. Loquens, 2(1), e018. doi: http://dx.doi.org/10.3989/loquens.2015.018

\begin{abstract}
The present research aims at determining to what extent an orthographic error related to the accent mark affects the visual recognition of Spanish words. For this, we conducted two experiments of visual lexical decision (with no word production), in which Spanish-speaking participants were instructed to ignore the presence or the absence of the accent mark.

Stimuli were composed of words originally without accent mark ( $O r N A$ for 'originally no accent'; Experiment 1) and words originally with an accent mark ( $O r W A$ for 'originally with accent'; Experiments 1 and 2). OrNA words were presented in three conditions: correctly spelled (e.g., dulce 'sweet'), with an added accent mark on the lexically stressed vowel (dúlce) and with a misplaced accent mark on the lexically non-stressed vowel (dulcé). Along the same line, OrWA words were also presented in three conditions: correctly spelled (e.g., lápiz 'pen'), without the accent mark (lapiz) and with a misplaced accent mark (lapiz).
\end{abstract}

Taken together, the results showed that the accent mark plays a role in the visual word recognition in Spanish. More specifically, the addition and/or the misplacement of an accent mark significantly slow down the visual recognition of the words, whereas the omission of the accent mark does not. The findings are discussed within the framework of dual-route models.

Keywords: Spanish; accent mark; visual word recognition; lexical stress; lexical access.

RESUMEN: Marca acentual y reconocimiento visual de palabras en español.- Esta investigación tiene como meta determinar en qué medida un error ortográfico relativo al acento gráfico (i.e., tilde) afecta al reconocimiento visual de las palabras en español. Para ello, realizamos dos experimentos de decisión léxica visual (sin producción de las palabras), en los que los participantes tenían que ignorar la presencia o ausencia del acento gráfico.

Los estímulos se componían de palabras originalmente sin acento gráfico (OrNA para 'originally no accent'; Experimento 1) y palabras originalmente con acento gráfico (OrWA para 'originally with accent'; Experimentos 1 y 2). Las palabras OrNA se presentaron en tres condiciones: correctamente ortografiadas (p. ej., dulce), con un acento gráfico en la vocal tónica (dúlce) y con un acento mal colocado en la vocal átona (dulcé). Asimismo, las palabras OrWA también se presentaron en tres condiciones: correctamente ortografiadas (p. ej., lápiz), sin el acento gráfico (lapiz) y con el acento gráfico mal colocado (lapíz).

Los resultados mostraron que el acento gráfico desempeña un papel en el reconocimiento visual de las palabras. Más específicamente, la adición y/o la mala colocación del acento gráfico ralentizan significativamente el reconocimiento visual de las palabras, mientras que la omisión del acento gráfico no lo dificulta. Discutimos los resultados dentro del marco de los modelos de doble ruta.

Palabras clave: español; acento gráfico; reconocimiento visual; acento léxico; acceso al léxico. 


\section{INTRODUCTION}

The emergence of social networking sites, internet chat rooms or mobile messaging applications brings to light an increasing use of variant spellings (e.g., Eisenstein, 2013). Indeed, users of these applications type their messages quickly and generally do not consider that they need to correct typos or to conform to spelling rules (e.g., The English Spelling Society, 2010).

In Spanish, a language with a mostly transparent orthography (i.e., except for very few cases, most letters equal one sound; about the orthographic depth see, for example, Frost \& Katz, 1992), the most common spelling errors concern the accent mark (e.g., carcel instead of cárcel 'jail'). Indeed, Jara Murillo (2013) found that $84 \%$ of the spelling errors identified in a Costa Rican Spanish corpus (COCAE) composed of Internet texts (blogs, chat rooms, etc.) were due to the omission of the accent mark.

Yet, the question arises whether an orthographic error relating to the accent mark affects the visual recognition of a Spanish word. In other words, are the Spanish-speaking readers hampered by accent mark errors?

Before describing the experiments that aim at answering this question, we first present, in the next subsections, the lexical stress and the use of accent mark in Spanish. Then, after a brief description of the visual word recognition models, we address the issue of stress assignment in visual word recognition with and without word production in Spanish.

\subsection{Lexical stress and use of accent mark in Spanish}

Lexical stress (or primary stress) is a phonological property of the word which specifies which syllable within the word is more prominent than the others. In that respect, Spanish is traditionally considered as a free-stress language ${ }^{1}$ (in opposition to fixed-stress languages, such as French; see, for example, Quilis, 1981, 1993). Indeed, we find Spanish words with lexical stress on the final syllable (i.e., oxytone words; e.g., explicar /ekspli'kar/ 'to explain'), on the penultimate syllable (i.e., paroxytone words; e.g., explico /eks' pliko/ 'I explain') or on the antepenultimate syllable (i.e., proparoxytone words; e.g., pájaro /'paxaro/ 'bird'). ${ }^{2}$ Lexical stress has a distinctive function in Spanish since it distinguishes, at the accentual level, segmentally identical words such as válido (/ 'balido/; adjective, 'valid'), valido (/ba'lido/; verb, 'I validate') and validó (/bali'do/; verb, 'he validated').

Although the three accentual patterns are present in Spanish, the paroxytone pattern is by far the most gener- al. For example, Quilis (1993) examined a corpus composed of 9219 Spanish words of different grammatical categories such as verbs, nouns, etc. (excluding monosyllabic and unaccented words), and found that $80 \%$ of the words were paroxytone, whereas approximately $17 \%$ of the words were oxytone and 3\% were proparoxytone. Therefore, the paroxytone pattern can be considered as the default accentual pattern in Spanish.

At the orthographic level, an accent mark is used in Spanish to indicate the stressed syllable only in specific cases. Following the Spanish spelling rules (Real Academia Española y Asociación de Academias de la Lengua Española, 2005) and as can be seen in Table 1, the accent mark is always required in proparoxytone words (e.g., pájaro), whereas its presence on paroyxytone and oxytone words depends on the structure of the final syllable of the word. Paroxytone words must be written with the accent mark (on the penultimate syllable) only when they end in a consonant other than $-\mathrm{n}$ or $-\mathrm{s}$ (e.g., cárcel). Along the same line, oxytone words must be spelled with the accent mark (on the final syllable) only when they end in a vowel or in $-\mathrm{n}$ or $-\mathrm{s}$ (e.g., bambú 'bamboo').

The assignment of stress in reading aloud can thus be deduced from the written form of the word, more specifically, from the presence of an accent mark, or, when there is no accent mark, from the structure of the final syllable of the word. For example, a word that ends in a vowel and has no accent mark (e.g., dulce, 'sweet') should be read as paroxytone (i.e., stress on the penultimate syllable, / 'dulOe/). Along the same line, a word that ends in a consonant and has an accent mark on the penultimate syllable (e.g., cárcel) should also be read as paroxytone (i.e., stress on the penultimate syllable, /'karOel/).

\subsection{Visual word recognition models}

A crucial issue in the examination of silent reading is to determine to what extent the visual representation of a printed word is phonologically recoded to be accessed in the lexicon. The models of visual word recognition can be classified according to the importance they give to the phonological code during lexical access (see Ferrand, 2001, for a description). Some models assume a direct access from the orthographic representation to the lexical representation, with no phonological recoding (e.g., Morton, 1969). On the contrary, other models postulate that the written words are necessarily recoded into a phonological code in order to access the lexical representations (e.g., van Orden, 1987). In between these two strong positions are dual-access models that combine di-

\footnotetext{
${ }^{1}$ Note that the use of the traditional "free-stress" terminology does not imply that the lexical stress is not structurally governed by phonological factors (e.g., syllable structure) and/or by morphological factors (i.e., the lexical stress is extensively used in the Spanish verbal morphology).

${ }^{2}$ Some adverbs ending in -mente have two stressed syllables (e.g. comúnmente /ko,mun'mente/ 'commonly') and some words, due to enclitics, present a stress on the fourth-to-last syllable (e.g., comiéndoselo /ko'mjendoselo/ 'eating it'; Quilis, 1993).
} 
Table 1. Examples of proparoxytone, paroxytone and oxytone Spanish words with and without accent mark.

\begin{tabular}{|c|c|c|c|c|c|}
\hline Lexical stress & $\begin{array}{l}\text { Final syllable } \\
\text { of the word }\end{array}$ & Accent mark & \multicolumn{3}{|c|}{ Examples } \\
\hline $\begin{array}{l}\text { Proparoxytone } \\
\text { words (PP) }\end{array}$ & Not specified & Always required & pájaro & /'paxaro/ & 'bird' \\
\hline \multirow{2}{*}{$\begin{array}{l}\text { Paroxytone } \\
\text { words (P) }\end{array}$} & $\begin{array}{l}\text { Ending with a vowel } \\
\text { Ending with }-\mathrm{n} \text { or }-\mathrm{s}\end{array}$ & Not required & $\begin{array}{l}\text { dulce } \\
\text { rosas }\end{array}$ & $\begin{array}{l}\text { /'dulӨe/ } \\
\text { /'rosas/ }\end{array}$ & $\begin{array}{l}\text { 'sweet' } \\
\text { 'roses' }\end{array}$ \\
\hline & $\begin{array}{l}\text { Ending with a consonant } \\
\text { other than }-\mathrm{n} \text { or }-\mathrm{s}\end{array}$ & Required & $\begin{array}{l}\text { cárcel } \\
\text { lápiz }\end{array}$ & 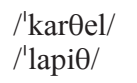 & $\begin{array}{l}\text { 'jail' } \\
\text { 'pencil' }\end{array}$ \\
\hline \multirow{2}{*}{$\begin{array}{c}\text { Oxytone } \\
\text { words }(\mathrm{O})\end{array}$} & $\begin{array}{l}\text { Ending with a consonant } \\
\text { other than }-\mathrm{n} \text { or }-\mathrm{s}\end{array}$ & Not required & $\begin{array}{l}\text { temor } \\
\text { moral }\end{array}$ & $\begin{array}{l}\text { /te'mor/ } \\
\text { /mo'ral/ }\end{array}$ & $\begin{array}{l}\text { 'fear' } \\
\text { 'moral' }\end{array}$ \\
\hline & $\begin{array}{l}\text { Ending with a vowel } \\
\text { Ending with }-\mathrm{n} \text { or }-\mathrm{s}\end{array}$ & Required & $\begin{array}{l}\text { bambú } \\
\text { pasión }\end{array}$ & $\begin{array}{l}\text { /bam'bu/ } \\
\text { /pa'sjon/ }\end{array}$ & $\begin{array}{l}\text { 'bamboo' } \\
\text { 'passion' }\end{array}$ \\
\hline
\end{tabular}

rect access and phonological recoding, in the sense that they consider that the orthographic and phonological information are possible and separate sources of activation in the identification of written words. Among these models are, for example, the Dual-Route Cascade model (Coltheart, Rastle, Perry, Langdon, \& Ziegler, 2001), the Parallel Distributed Processing model (Seidenberg \& McClelland, 1989) or the Connectionist Dual Process model (Perry, Ziegler, \& Zorzi, 2010, 2014). Despite the fact that these models differ in the way they consider the organization of the lexical representations (e.g., local or distributed) and the processing for words and pseudowords (different or similar), they share the idea that the orthographic code is dominant (i.e., the orthographic information is generally sufficient for reading) and that the phonological recoding is optional and necessary only in some specific conditions.

It has been claimed that speakers of opaque languages (that is, with non-transparent orthography, such as English or French; Frost \& Katz, 1992) use both lexical and nonlexical routes (e.g., Coltheart et al., 2001). On the other hand, the lexical route might not be necessary in transparent languages (that is, with transparent orthography, such as German or Spanish; Frost \& Katz, 1992), since words can be read using only grapheme-phoneme conversion rules (i.e., via the nonlexical route). However, researchers have found the presence of lexical effects (e.g., frequency, neighbourhood), in German (Ziegler, Perry, \& Coltheart, 2000) or in Spanish (González-Nosti, Barbón, RodríguezFerreiro, \& Cuetos, 2014; Martín Plasencia, Iglesias Dorado, \& Serrano, 2008) in reading aloud as well as in lexical decision tasks, which evidenced the use of the lexical route in transparent languages too.

In free-stress languages such English, Italian or Spanish, the nonlexical route should involve the use of rules not only about how to read segments, but also where to assign lexical stress, since it has been showed that readers impose lexical stress and intonation during silent reading (e.g., Ashby \& Clifton, 2005; Gross, Millett, Bartek, Bredell, \& Winegard, 2013), and that lexical stress plays a role in lexical access (e.g., Soto-Faraco, Sebastián-Gallés, \& Cutler, 2001). Although this is not an easy task in languages with unpredictable stress (such as English or Italian), some models have successfully integrated rules to assign lexical stress (see, for example, Perry, Ziegler, \& Zorzi, 2010; Rastle \& Coltheart, 2000; Ševa, Monaghan, \& Arciuli, 2009, for English; and Pagliuca \& Monaghan, 2010; Perry, Ziegler, \& Zorzi, 2014, for Italian). In Spanish, however, the position of stress, as seen in the previous section, can easily be predicted from the written form of a word thanks to the presence of an accent mark or to the structure of the final syllable of the word. Thus, as stated by Gutiérrez Palma and Palma Reyes (2008), stress rules might easily be integrated within the grapheme-phoneme conversion rules in the nonlexical route.

\subsection{Stress assignment in visual word recognition with and without word production in Spanish}

Given that stress assignment in word production in Spanish has been very little examined, we report in this section some studies on Greek and Italian, since these two languages share with Spanish some accentual properties (i.e., free-stress language) and orthographic characteristics (i.e., the lexical stress is marked, to different extent, with an accent mark).

Protopapas, Gerakaki, and Stella (2007) mentioned that the stress assignment in word production (for example, in a reading aloud task) is made possible through various sources of information. Since the Greek stress is always marked by an accent mark in polysyllabic words, the orthographic information (i.e., the accent mark) plays a crucial role in the stress assignment in Greek. A second source of information in the stress assignment is lexical, as the speaker can retrieve the stress pattern of the words from the information in the lexicon. In that sense, more accentual errors are likely to be observed in the production of pseudowords than in the production of 
words, since pseudowords cannot be found in the lexicon. Moreover, word-resembling pseudowords are more likely to be produced with the stress of the resembling word. A third source of information might determine, to a lesser extent, the stress assignment in Greek: the default stress pattern information. Since the Greek default stress pattern is paroxytone, speakers are likely to produce, in absence of other sources of information, paroxytone items.

Research in Italian has shown that stress can be assigned not only on the basis of the lexical information and on the default accentual pattern, but also on the basis of the stress neighborhood consistency (e.g., many Italian words ending in -ino are paroxytone, such as bambino; Colombo, 1992; Colombo, Deguchi, \& Boureux, 2014; Colombo \& Zevin, 2009). For example, Colombo and Zevin (2009), with the pathway priming paradigm (i.e., a sequence of primes with the same stress precedes a target), found that the neighborhood consistency plays a role in the stress assignment. Indeed, they reported that speakers were sensitive to the relationship between particular segmental patterns and stress, since they produced pseudowords with the less frequent stress pattern on the basis of the stress neighbors.

In Spanish, the only study, to our knowledge, that deals with stress assignment in word production was performed by Gutiérrez Palma and Palma Reyes (2004). They studied the stress placement in a reading-aloud task with children. More specifically, they examined, on the one hand, the use of the information about the default stress pattern in the stress assignment in Spanish. On the other hand, since the authors consider the difference between regular and irregular words as being determinant in stress assignment (i.e., words considered as regular are paroxytone words ending with a vowel and oxytone words ending with a consonant), they also explored the importance of the word syllabic structure in stress assignment. For this, 18 8-year-old children had to read aloud paroxytone (e.g., cable) and oxytone (e.g., collar) words, as well as regular (e.g., compra) and irregular (e.g., café) words. The words appeared on a computer screen in capital letters without accent mark. Reaction times (RTs) and errors were collected. Regarding the default stress pattern information, the authors failed to show a difference in RTs and error rates between the production of paroxytone (i.e., default accentual pattern) and oxytone words. As far as the syllabic information was concerned, they found more errors in irregular words (i.e., where stress did not match the syllable structure) than in regular words, but no difference in RTs, and concluded that the syllabic information (i.e., regularity) is used in the stress assignment in Spanish.

The question arises whether lexical stress plays the same role in lexical access when there is no word production, for example in lexical decision tasks. To our knowledge, very few studies have dealt with this issue in Spanish.

Soto-Faraco, Sebastián-Gallés, and Cutler (2001) examined with a crossmodal priming method the role of lexical stress in the activation of spoken words. In their experiment, the prime was an auditory two-syllable sequence such as prínci- (/prin $\theta \mathrm{i} /)$ followed by a visual word target which could match the prime stress pattern (e.g., príncipe /'prin日ipe/) or not (e.g., principio / prin'(ipjo/). Results showed that stress-mismatching primes slowed down the responses. The authors concluded that Spanish listeners use lexical stress information in lexical access.

Domínguez and Cuetos (2001) investigated the role of lexical stress in a lexical decision task, where both primes and targets were visual. In their experiment, they examined the priming effect in three conditions. In the first condition, the prime and target were orthographically related (but stress-unrelated) pairs. For example, rasgó and rasgo present a similar orthography but different stress patterns, the former being oxytone and the latter paroxytone. In the second condition, the prime and target were orthographically unrelated (but stress-related) pairs. For example, persa and rasgo present a different orthography but the same paroxytone stress patterns. Finally, in the third condition, the prime and target were totally unrelated pairs. For example, dormi and rasgo present a different orthography and different stress patterns, the former being oxytone and the latter paroxytone. Results showed no priming difference between orthographically related pairs (rasgó/rasgo) and orthographically unrelated pairs (persa/rasgo), whereas they showed a difference between orthographically related pairs (rasgó/rasgo) and totally unrelated pairs (dor$\mathrm{mi}^{\prime} / \mathrm{rasgo}$ ), as well as between orthographically unrelated pairs (persa/rasgo) and totally unrelated pairs (dormíl rasgo). The authors pointed out that the priming effect observed in the orthographically related pairs (rasgó/ rasgo) was due to the orthographic overlap between both words, while the priming effect in the orthographically unrelated pairs (persa/rasgo) was due to the stress overlap (i.e., both words are paroxytone), and therefore concluded that lexical stress is a "prelexical element that the visual word recognition system uses to arrive at the lexicon"

A few years later, Gutiérrez Palma and Palma Reyes (2008) investigated the use of the accent mark in the lexical access in Spanish since the position of stress in Spanish can be known - thanks to the accent mark-before lexical access is complete. In their research, they examined the priming effect in pairs of words presented with different SOA (Stimulus Onset Asynchrony) and in three conditions. In the identity condition, the prime was the same as the target (e.g., actor-ACTOR). In the correct stress condition, the prime had an accent mark on the stressed vowel, and prime and target shared the same accentual pattern (actór-ACTOR). Finally, in the misstress condition, the prime had an accent mark on the non-stressed vowel, and prime and target did not share the same accentual pattern (áctor-ACTOR). The absence of a difference between the identity and correct stress conditions, as well as the presence of a difference between the correct and mis-stress conditions suggest, ac- 
cording to the authors, that the accent mark is a phonological rather than an orthographical cue for lexical access. Moreover, the authors concluded that lexical stress affects lexical access at late stages of the processing, since the priming effect was observed at long SOA only ${ }^{3}$.

\subsection{Research questions}

The present research aims at shedding more light on the role of the accent mark in visual word recognition in Spanish. More specifically, the goal is to determine to what extent an orthographic error related to the accent mark (i.e., omission, addition and misplacement) slows down the recognition of the word in a lexical decision task (with no word production).

Two main experimental differences will be found in respect with the studies that have been previously described. The first difference concerns the stimuli used in the experiment. Contrary to Gutiérrez Palma and Palma Reyes (2008), who only used target words with no accent mark, in the present experiment we used stimuli with and with no accent mark (lápiz 'pen'; dulce). The second difference concerns the experimental task. We used a visual lexical decision task (with no priming) in which the participants had to ignore the presence or the absence of the accent mark when they made their decision about the printed stimulus being an existing word or not. To our mind, this task was the most appropriate to examine the impact of an accent mark misspelling on the visual word recognition, since it reflects the everyday situation in which a reader can be faced with a word containing an accent mark error.

\section{EXPERIMENT 1}

\subsection{Method}

\subsubsection{Participants}

Twenty-two Spanish-speaking participants took part in this study. They were all Costa Rican Philology students at the Universidad de Costa Rica (16 females and 6 males aged between 18 and 33 years; mean age $=26$ years) and were paid for their participation in the experiment. All of them had normal or corrected-to-normal vision.

\subsubsection{Material}

Spanish disyllabic words (verbs, nouns or adjectives) and pseudowords composed of 4 to 6 letters were used in this experiment. As far as the words are concerned, half of them $(N=30)$ did not have any accent mark (OrNA, for 'Originally No Accent'): among them, 15 were paroxytone $(\mathrm{P}$; e.g., dulce) and 15 were oxytone $(\mathrm{O}$; e.g., temor, 'fear'). The other half of the words $(N=30)$ had an accent mark (OrWA, for 'Originally With Accent'): among them, 15 were paroxytone (P; e.g., lápiz) and 15 were oxytone (O; e.g., pasión 'passion'). Given that it was not possible to select paroxytone and oxytone words with similar frequencies within OrNA and OrWA (Alameda \& Cuetos, 1995), the selected words presented a wide range of frequencies, whose effect would be controlled in the analyses. The list of words appears in Appendix A1 with the following information: the accentual pattern, the presence/absence of an accent mark, the number of letters, the lexical frequency (Alameda \& Cuetos, 1995), and the number and frequency of orthographic neighbors (Pérez, Alameda, \& Cuetos Vega, 2003).

The words with no accent mark (OrNA) - paroxytone (e.g., dulce) or oxytone (e.g., temor) - , appeared in the three following conditions: Baseline, Added and Misplaced. In the Baseline condition, the word appeared in its original form (that is, with no accent mark: dulce, temor). In the Added condition, an accent mark was added on the lexically stressed vowel (i.e., on the penultimate syllable in paroxytone words and on the last syllable in oxytone words: dúlce, temór, respectively). In the Misplaced condition, an accent mark was added on the lexically non-stressed vowel (that is, on the last syllable in paroxytone words and on the penultimate syllable in oxytone words: dulcé, témor, respectively).

The words with an accent mark (OrWA) - paroxytone (e.g., lápiz) or oxytone (e.g., pasión) - appeared in the three following conditions: Baseline, Omitted and Misplaced. In the Baseline condition, the word appeared in its original form (i.e., with the accent mark: lápiz, pasión, respectively). In the Omitted condition, the accent mark was omitted (lapiz, pasion, respectively). In the Misplaced condition, the accent mark was misplaced on the lexically non-stressed vowel (that is, on the last syllable in the paroxytone words and on the penultimate syllable in oxytone words: lapíz, pásion, respectively). Despite the fact that the Added, Omitted and Misplaced stimuli do not exist in Spanish, they are considered as real words in this experiment (see section 2.1.3).

\footnotetext{
${ }^{3}$ Protopapas (in press) showed reserves on the activation of the abstract metrical information during visual word recognition. According to him, given that in Gutiérrez Palma and Palma Reyes (2008), the word primed itself in the mental lexicon (since prime and target were the same word but with a diacritic difference), the priming effect did not refer to stress per se. Indeed, stress pattern, which is just a property of the word in the lexicon, was primed along with the entire lexical representation. Still according to Protopapas (in press), if metrical frames are activated as a result of visual word processing, then stress priming effects should be observed in pairs of stimuli that are segmentally different but matched in stress. To verify this hypothesis, he conducted various experiments to test whether stress patterns were activated by visual word recognition and visual pseudoword decoding. No stress priming was observed, either for words or for pseudowords. The author concluded that "it seems that metrical frames are not activated independently of specific lexical representations" (p. 16).
} 
Table 2 shows the orthographic and phonological differences between each condition (Added, Misplaced and Omitted) and the Baseline condition. Orthographic difference refers to a graphical (i.e., accent mark) difference, while phonological difference refers to a difference in the position of stress. For example, following the Spanish accentuation rules, the Baseline stimulus dulce is paroxytone since it ends with a vowel. Its corresponding Added stimulus dúlce is paroxytone due to the accent mark. Thus, dulce and dúlce share the same accentual (phonological) pattern (that is, paroxytone). On the other hand, the corresponding Misplaced stimulus dulcé, which is oxytone due to the accent mark, is phonologically (i.e., accentually) different from the Baseline stimulus dulce.

Pseudowords were created from the words by modifying a vowel or a consonant (e.g., *dulpe), with the consequence that the corresponding word (dulce) was the orthographic neighbor of the pseudoword $(*$ dulpe). In order to counterbalance the number of words and pseudowords, the pseudowords appeared in the same conditions as the words, as can be seen in Table 3. The list of pseudowords appears in Appendix A2.

In total, 180 words $(60 \times 3$ conditions $)$ and 180 pseudowords were used in this experiment. The stimuli were distributed in three parts. The number of words and pseudowords, the number of Baseline, Added, Omitted and Misplaced stimuli and the number of stimuli originally with and with no accent (OrWA and OrNA) were counterbalanced across the three parts. The part order (e.g., 1-2$3,2-3-1,3-2-1$, etc.) was counterbalanced across partic- ipants. Within each part, each participant received a different randomization of the stimuli.

\subsubsection{Procedure}

The experiment was run using DMDX software (Forster, 2015). Participants performed a visual lexical decision task. On each trial, an asterisk appeared on the computer screen replaced after $500 \mathrm{~ms}$ by a letter string. The participants had to indicate whether the letter string was a Spanish word or not by pressing as quickly as possible the key 'Sí' or the key 'No'. In their decision about whether the letter string was a Spanish word or not, the participants had to ignore the presence or the absence of the accent mark. For example, the letter string lapiz had to be considered as a word despite the absence of the accent mark on $a$. The participants had 2.5 seconds to answer, and after $500 \mathrm{~ms}$ the next trial was presented. The experiment lasted about 30 minutes and was run in a quiet room in the Universidad de Costa Rica.

\subsubsection{Data analysis}

Given that the error rates were very low (mean = $2.49 \%$; range: $0 \%-7.8 \%$ ), they were not further analyzed. Only RTs for the correct responses on the words were analyzed. One item (inglés 'English') had to be excluded from the analysis because the word in the Omitted condition (i.e., ingles 'groins') existed.

Table 2. Orthographic and phonological differences between each condition (Added, Misplaced and Omitted) and Baseline condition for OrNA and OrWA stimuli.

\begin{tabular}{|c|c|c|c|}
\hline \multicolumn{2}{|c|}{$\begin{array}{c}\text { Without accent mark (OrNA) } \\
\text { (e.g., dulce, temor) }\end{array}$} & \multicolumn{2}{|c|}{$\begin{array}{l}\text { With accent mark (OrWA) } \\
\text { (e.g., lápiz, pasión) }\end{array}$} \\
\hline $\begin{array}{c}\text { Added } \\
\text { (dúlce, temór })\end{array}$ & $\begin{array}{c}\text { Misplaced } \\
(\text { dulcé, témor })\end{array}$ & $\begin{array}{c}\text { Omitted } \\
\text { (lapiz, pasion) }\end{array}$ & $\begin{array}{l}\text { Misplaced } \\
\text { (lapiz, pásion) }\end{array}$ \\
\hline $\begin{array}{l}\text { Orthographic, but no } \\
\text { phonological difference } \\
\text { with Baseline } \\
(\text { dulce, temor })\end{array}$ & $\begin{array}{c}\text { Orthographic and } \\
\text { phonological difference } \\
\text { with Baseline } \\
(\text { dulce, temor })\end{array}$ & $\begin{array}{c}\text { Orthographic and } \\
\text { phonological difference } \\
\text { with Baseline } \\
\text { (lápiz, pasión) }\end{array}$ & $\begin{array}{l}\text { Orthographic and } \\
\text { phonological difference } \\
\text { with Baseline } \\
\text { (lápiz, pasión) }\end{array}$ \\
\hline
\end{tabular}

Table 3. Examples of words and pseudowords used in Experiment 1.

\begin{tabular}{|c|c|c|c|c|c|}
\hline \multirow[b]{2}{*}{ Spelling } & \multirow[b]{2}{*}{ Condition } & \multicolumn{2}{|c|}{ Words } & \multicolumn{2}{|c|}{ Pseudowords } \\
\hline & & $\begin{array}{c}\text { Paroxytone } \\
(\mathrm{P}) \\
(N=90)\end{array}$ & $\begin{array}{c}\text { Oxytone } \\
(\mathrm{O}) \\
(N=90)\end{array}$ & $\begin{array}{c}\text { Paroxytone } \\
(\mathrm{P}) \\
(N=90)\end{array}$ & $\begin{array}{c}\text { Oxytone } \\
(\mathrm{O}) \\
(N=90)\end{array}$ \\
\hline \multirow{3}{*}{$\begin{array}{c}\text { Without accent } \\
\text { mark } \\
\text { (OrNA) }\end{array}$} & Baseline & dulce & temor & *dulpe & *tamor \\
\hline & Added & dúlce & temór & *dúlpe & *tamór \\
\hline & Misplaced & dulcé & témor & *dulpé & *támor \\
\hline \multirow{3}{*}{$\begin{array}{l}\text { With accent mark } \\
\text { (OrWA) }\end{array}$} & Baseline & lápiz & pasión & *lámiz & *pasián \\
\hline & Omitted & lapiz & pasion & *lamiz & *pasian \\
\hline & Misplaced & lapiz & pásion & *lamíz & *pásian \\
\hline
\end{tabular}


Statistical analyses were carried out with the R software (version 3.1.3) and its lmerTest package (v. 2.0-20; Kuznetsova, Brockhoff, \& Christensen, 2014) on lntransformed RTs. We ran two separate analyses for the words originally with no accent mark (OrNA) and for the words originally with an accent mark (OrWA).

Data were analyzed by means of mixed-effects regression models (Baayen, Davidson, \& Bates, 2008), in which participants and items were entered as random variables. In both analyses (OrNA and OrWA), the predictor was Condition (Baseline/Added/Misplaced for OrNA and Baseline/Omitted/Misplaced for OrWA). The following control variables were also entered into the analyses in order to ensure that the effects we report were not driven by differences in these variables: accentual pattern ( $\mathrm{P}$ and $\mathrm{O})$, number of letters in the word $(4,5$ and 6 letters, considered as a nominal variable), word frequency $(\log 10$ transformed and centered on the mean), number of the word orthographic neighbors ${ }^{4}$ (centered on the mean) and presentation order (centered on the mean).

The results we report in the following section come from models where only control variables that reached significance were retained ${ }^{5}$. Significance was assessed using a $p$-value (from the Satterthwaite approximation for degrees of freedom implemented in the lmerTest package) below 0.05 for the main effects and a $t$-value above 1.96 for the estimates. Following Baayen (2008), in order to ensure that the results in our final models were not driven by a few atypical data points, residuals larger than 2.5 times the standard deviation were considered outliers and removed.

\subsection{Results}

\subsubsection{Words originally with no accent mark $(\mathrm{OrNA})^{6}$}

The results of the final model are presented in Table $4^{7}$. As for the control variables, only two were significant. As can be seen, we observe an effect of word frequency (i.e., the higher the word frequency, the faster the RTs) and an effect of the presentation order (i.e., the further in the experiment, the faster the RTs).

As shown in Table 4, results also present an effect of condition. Baseline stimuli (i.e., correctly spelled) are recognized faster $(763 \mathrm{~ms})$ than Added stimuli $(831 \mathrm{~ms})$ and Misplaced stimuli (832 $\mathrm{ms})$, whereas the RTs for Added and Misplaced stimuli are not significantly different. Indeed, as can be seen in Figure 1, the addition of an accent mark on the stressed vowel of the word (Added condition) creates a processing cost in comparison with the correctly spelled words (Baseline condition). Along the same line, the addition of an accent mark on the nonstressed vowel of the word (Misplaced condition) also involves a processing cost relative to the correctly spelled words (Baseline condition). Finally, Added and Misplaced stimuli result in a similar processing cost.

\subsubsection{Words originally with accent mark (OrWA)}

The results of the final model are presented in Table $5^{8}$. As for the control variables, we only observe an effect of word frequency (i.e., the higher the word fre-

Table 4. Summary of the mixed-effects regression model for reaction times for OrNA stimuli in Experiment 1.

\begin{tabular}{lccccc}
\hline \multicolumn{1}{c}{ Variable } & $\boldsymbol{\beta}$ & $\mathbf{S E}$ & $\mathbf{t}$ & $(\boldsymbol{d} \boldsymbol{f}) \mathbf{F}$ & $\boldsymbol{p}$-values (F-tests) \\
\hline Word frequency & -0.13650 & 0.01093 & -12.50 & $(1,90)=156.13$ & $(1,1782)=63.66$ \\
\hline Presentation order & -0.00036 & 0.00004 & -7.98 & $(2,85)=23.17$ & $p<.001$ \\
\hline Condition & & & & & \\
Baseline vs. Added & 0.08002 & 0.01441 & 5.55 & & \\
Baseline vs. Misplaced & 0.08929 & 0.01448 & 6.17 & & \\
Added vs. Misplaced & 0.00927 & 0.01453 & 0.64 & & \\
\hline
\end{tabular}

\footnotetext{
${ }^{4}$ Given that a strong correlation $(r=.75, p<.001)$ was found between the number and the frequency of the word orthographic neighbors, we only entered the number of the word neighbors into the model.

${ }^{5}$ We also examined the interaction between each control variable and the predictor (i.e., Condition). As none was significant, they were not entered into the final model.

${ }^{6}$ In a preliminary analysis performed on the Baseline stimuli only, we examined whether original spelling (OrNA/OrWA) and accentual pattern $(\mathrm{P} / \mathrm{O})$ had an effect on RTs. No differences were observed between OrNA and OrWA, $\mathrm{F}(1,54)=0.045$, ns, or between paroxytone and oxytone stimuli, $F(1,54)=0.00, n s$, and no interaction between the two variables was observed, $F(1,54)=0.17, n s$. The absence of a difference between words with and without accent mark suggests that the processing of the accent mark, which might be considered as an additional character to be processed, does not slow down the recognition of the words.

${ }^{7}$ Given that the examination of the assumption of the normality of residuals and random effects revealed the presence of one outlier among the participants, we also performed the analysis without this outlier. The results with the exclusion of this participant were similar to the results presented in Table 4

${ }^{8}$ Given that the examination of the assumption of the normality of residuals and random effects revealed the presence of one outlier among the participants (the same as in OrNA), we also ran the analysis without it. The results with the exclusion of this participant were similar to the results presented in Table 5 .
} 
Figure 1. Reaction time (ms) for the OrNA stimuli as a function of the condition (Baseline: base stimuli; Added: stimuli with an added accent mark; Misplaced: stimuli with an added misplaced accent mark). Data for paroxytone (e.g., dulce) and oxytone stimuli (e.g., temor) are grouped together. The error bars are standard errors of the mean.

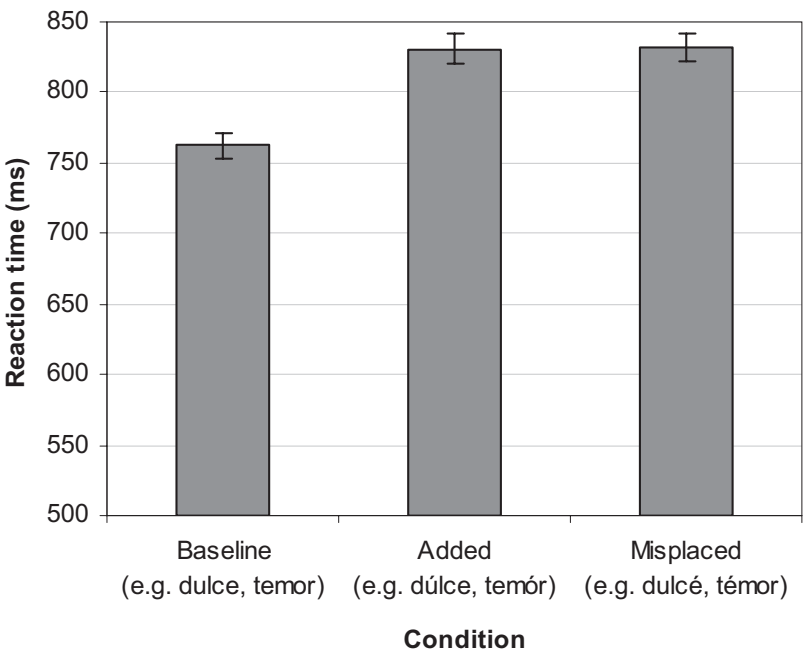

Figure 2. Reaction times (ms) for the OrWA stimuli as a function of the condition (Baseline: base stimuli; Omitted: stimuli with an omitted accent mark; Misplaced: stimuli with a misplaced accent mark). Data for paroxytone (e.g., lápiz) and oxytone stimuli (e.g., pasión) are grouped together. The error bars are standard errors of the mean.

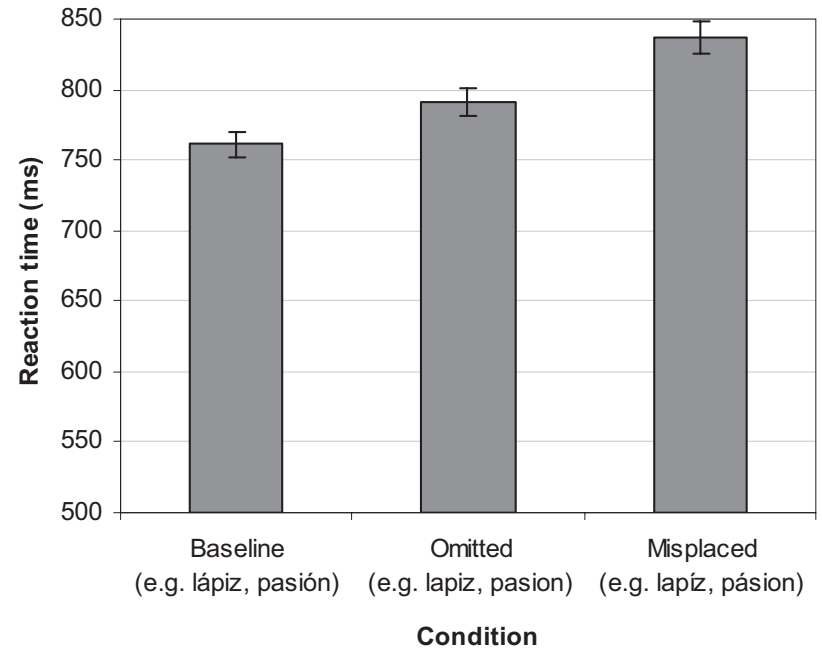

Table 5. Summary of the mixed-effects regression model for reaction times for OrWA stimuli in Experiment 1.

\begin{tabular}{|c|c|c|c|c|c|}
\hline Variable & $\beta$ & SE & $\mathbf{t}$ & $(d f) \mathrm{F}$ & $p$-values (F-tests) \\
\hline Word frequency & -0.07110 & 0.01674 & -4.25 & $(1,82)=18.03$ & $p<.001$ \\
\hline Presentation order & -0.00029 & 0.00004 & -6.25 & $(1,1732)=39.01$ & $p<.001$ \\
\hline Condition (Baseline) & & & & $(2,82)=6.74$ & $p<.01$ \\
\hline Baseline vs. Omitted & 0.03167 & 0.02040 & 1.55 & & \\
\hline Baseline vs. Misplaced & 0.07477 & 0.02044 & 3.66 & & \\
\hline Omitted vs. Misplaced & 0.04310 & 0.02046 & 2.11 & & \\
\hline
\end{tabular}

quency, the faster the RTs) and an effect of the presentation order (i.e., the further in the experiment, the faster the RTs).

As can be seen in Table 5, results also present an effect of condition. The difference between Baseline stimuli, that is, correctly spelled $(761 \mathrm{~ms})$ and Omitted stimuli (790 ms) just failed to reach significance, whereas the difference between Baseline stimuli (761 ms) and Misplaced stimuli $(837 \mathrm{~ms})$ is significant. RTs for Omitted stimuli are faster that RTs for Misplaced stimuli.

Indeed, as can be seen in Figure 2, the omission of the accent mark (Omitted condition) does not create a significant processing cost compared with the correctly spelled words (Baseline condition). On the other hand, the misplacement of the accent mark on the non-stressed vowel (Misplaced condition) involves a processing cost with respect to the correctly spelled word (Baseline condition). Finally, Misplaced stimuli create a larger processing cost (in comparison with Baseline stimuli) than Omitted stimuli.

\subsection{Discussion}

This experiment aimed at examining the role of the accent mark in the visual word recognition in Spanish. More specifically, our goal was to determine to what extent spelling errors concerning the accent mark hamper the recognition of the words. For this, participants performed a lexical decision task in which they were instructed to ignore the presence or the absence of the accent mark. Words originally with no accent mark (OrNA) were presented in three conditions: correctly spelled (e.g., dulce), with an added accent mark on the stressed vowel (dúlce) and with a misplaced accent mark on the non-stressed vowel (dulcé). Along the same line, words originally with an accent mark (OrWA) were presented in three conditions: correctly spelled (e.g., lápiz), without the accent mark (lapiz) and with a misplaced accent mark on the non-stressed vowel (lapíz). 
The fact that the error rate was very low $(2.49 \%)$ indicates that the participants were capable to perform the task reasonably well. Nevertheless, the RTs were relatively long (802 ms averaged across conditions for OrNA and OrWA) when compared to those reported by Zagar and Mathey (2000) for a similar task in French (654 ms averaged across conditions in Experiment 1). Thus, one could assume that the low error rate was obtained at a cost of high RTs. However, no significant correlation was found between participants' error rate and mean RT $(N=22 ; r=-.21, n s)$. Taken together, these findings suggest that despite the participants' high performance, the task was not easy for them.

As far as the words originally with no accent mark (OrNA; e.g., dulce) are concerned, the examination of the RTs showed an effect of condition, which indicates that neglecting the accent mark affected the time the participants needed to response. Results showed that the addition and the misplacement of the accent mark slowed down (in an equally way) the recognition of a word which usually does not have any accent mark. Thus, the accent mark appears to play a role in the visual word recognition in Spanish, as shown in previous studies (e.g., Gutiérrez Palma \& Palma Reyes, 2008).

Along the same line, an effect of condition was also observed for the word originally with an accent mark (OrWA; e.g., lápiz), suggesting again that neglecting the accent mark affected the participants' RTs. Nevertheless, the situation differs from OrNA words. Results have showed statistically similar RTs between the Baseline condition (e.g., lápiz) and the Omitted condition (e.g., lapiz), which indicates that the absence of the accent mark did not significantly hamper the recognition of the words usually written with an accent mark. On the contrary, a misplaced accent mark in the Misplaced condition (e.g., lapiz) significantly slowed down the word recognition, in comparison with the Baseline condition. These results are in agreement with Protopapas and Gerakaki (2009), who reported that the effect of removing the accent mark is weaker than the effect of misplacing it. As concluded by Protopapas (in press), the accent mark "needs not be processed to recognize and pronounce the word correctly" ( $p$. 13), but the accent mark "does become part of the orthographic image of the words, so that its misplacement can affect orthographic processing" (p. 13).

Moreover, an important point has to be mentioned concerning the plausibility of the words in the different conditions. According to the rules of the accent mark in Spanish, words in the Added condition in OrNA (e.g., dúlce) and in the Misplaced condition in OrWA (e.g., lapíz) are implausible, while words in the Misplaced condition in OrNA (dulcé) and in the Omitted condition in OrWA (lapiz) are plausible. In order to rule out the possible bias due to the implausibility of the words in some conditions, we examined the data for the pseudowords, since they were presented in the same conditions as the words. If the word plausibility plays a role in the visual word recognition, a difference between the RTs for plausible (e.g., *dulpe, *tamor) and implausible pseudowords (*dúlpe, *tamór) should be observed. However, no differ- ence was found between the former $(929 \mathrm{~ms})$ and the latter $(931 \mathrm{~ms})$ : $F(1,175)=0.16, n s$, which allows us to exclude a possible effect of the implausibility of the words in some conditions.

Our results also showed that the accentual pattern of the words does not affect the visual word recognition, since no differences between paroxytone words (e.g., dulce, lápiz) and oxytone words (e.g., temor, pasión) were found. These findings, in agreement with Gutiérrez Palma and Palma Reyes (2004), indicate that the default accentual pattern (that is, paroxytone in Spanish) does not show any advantage over another less frequent pattern (e.g., oxytone) in the visual recognition of existing words in Spanish.

This experiment presents however some limitations. First, the three presentations of each word (i.e., once in the three conditions, all in one block) might have caused some priming effects. The response on the second or third presentation of the word might have been faster, since the word was already activated by its first presentation. In order to avoid a possible bias due to these effects, different words should be presented in the different conditions (for example, cárcel in the Baseline condition and arbol 'in the Omitted condition).

Secondly, the fact that the pseudowords constituted orthographic neighbors of the words used in the experiment (for example, the word dulce is the neighbor of the pseudoword *dulpe) might have made the participants to reread stimuli several times in order to make sure of their decision. The similarity between the pseudowords and the words not only probably made the task more artificial than a task where words and pseudowords would be more different, but it might also have increased the aforementioned priming effects.

We conducted a second experiment in order to take these observations into account and to considerably simplify the experimental design. We focused our attention only on the Omitted condition of the OrWA words for two reasons. First, contrary to the other conditions that showed a significant 70 $\mathrm{ms}$ difference with Baseline, the $30 \mathrm{~ms}$ difference between the Omitted (e.g., lapiz) and Baseline (e.g., lápiz) conditions just failed to reach significance. Comparing these two conditions using a less complex design would enable us to confirm these tendentious results. Secondly, it has been reported that the most common spelling error in the Spanish orthography is the omission of the accent mark (e.g., Jara Murillo, 2013; Pujol, 2005). Thus, omitting the accent mark seems to be more frequent (i.e., more "natural") than adding or misplacing it. Moreover, since no difference was found between paroxytone and oxytone words, we only considered paroxytone words in Experiment 2, since this pattern is the most frequent in Spanish (Quilis, 1993).

\section{EXPERIMENT 2}

In this experiment, we used a simpler and more controlled experimental design that the one in Experiment 1 in order to examine to what extent the omission of the accent mark hampers the visual word recognition. 


\subsection{Method}

\subsubsection{Participants}

Forty native Spanish speakers from Barcelona took part in this experiment. They were all students at the Universitat Autònoma de Barcelona or at the Universitat Pompeu Fabra de Barcelona (31 females and 9 males aged between 19 and 33 years; mean age $=22$ years) and were paid for their participation in the experiment. All participants had normal or corrected-to-normal vision.

\subsubsection{Material}

Twenty-eight Spanish disyllabic paroxytone words (nouns or adjectives) of 5 or 6 letters with an accent mark (e.g., cárcel) were used in this experiment. The stimuli were presented in two conditions: with accent mark (i.e., Baseline; cárcel) and without accent mark (i.e., Omitted; carcel). The Baseline and Omitted words differed at the orthographic level (e.g., presence/absence of the accent mark), as well as at the phonological level, since Baseline words were paroxytone (cárcel), whereas Omitted words became oxytone (carcel) according to the rules of the written accentuation in Spanish.

Given that the neighbourhood frequency is susceptible to affect the recognition of the words (Mathey \& Zagar, 2006; Zagar \& Mathey, 2000), the selection of the words was carried out in such a way that the words had no orthographic neighbors with a higher frequency, whether they had the accent mark or not. For example, we excluded words such as mártir 'martyr', since the Omitted word martir presented an orthographic neighbor with a higher frequency (e.g., partir 'to break, to leave') than the Baseline word (mártir). The examination of the word neighbourhood was performed using NIM (Guasch, Boada, Ferré, \& Sánchez-Casas, 2013).
Furthermore, if the participants were presented with the same word in both conditions (Baseline and Omitted; e.g., cárcel and carcel), the aforementioned priming effect might occur, which might interfere in the results. In order to avoid this effect, we created two lists of stimuli that were presented to two different groups of participants.

For the creation of the two lists, care was taken that the number of letters, the word frequency (using NIM; Guasch et al., 2013), the number of orthographic neighbors (using NIM; Guasch et al., 2013) did not differ across the two lists and across the two conditions (Baseline and Omitted $)^{9}$, since these variables are known to affect the visual recognition of the words (e.g., GonzálezNosti et al., 2014, for lexical decision in Spanish). Furthermore, most of the words were nouns in both lists.

Moreover, 28 Spanish disyllabic paroxytone pseudowords of 5 or 6 letters with an accent mark (e.g., *námil) were created using Wuggy (Keeulers \& Brysbaert, 2010). The pseudowords were also distributed into the two lists and appeared with and without accent mark. Contrary to Experiment 1, the pseudowords (with or without accent mark) had no orthographic neighbors (according to NIM; Guasch et al., 2013). Furthermore, we made sure that the bigram frequency (computed with CLEARPOND; Marian, Bartolotti, Chabal, \& Shook, 2012) was similar between pseudowords and words in each list ${ }^{10}$. Table 6 provides some examples of the stimuli used in Experiment 2 and the list of the words and the pseudowords appears in Appendix B.

We also designed an evaluation of the knowledge concerning the use of the written accent marks in Spanish. This evaluation was divided into three exercises. For the first and the second exercises, we selected two lists of 28 Spanish words divided into proparoxytone, paroxytone and oxytone words of 2, 3 and 4 syllables. Half of the words had an accent mark and the other half did not. In the first exercise, we removed the accent mark (e.g., martir instead of mártir). In the second exercise, we removed

Table 6. Examples of the stimuli used in Experiment 2.

\begin{tabular}{lcccc}
\hline \multirow{2}{*}{ Condition } & \multicolumn{2}{c}{ List A } & \multicolumn{2}{c}{ List B } \\
\cline { 2 - 5 } & Word & Pseudowords & Words & Pseudowords \\
\hline Baseline & cárcel & $*$ námil & árbol & $*$ dépel \\
(i.e., with accent mark) & $(N=14)$ & $(N=14)$ & $(N=14)$ & $(N=14)$ \\
Omitted & arbol & $*$ depel & carcel & $*$ namil \\
(i.e., without accent mark) & $(N=14)$ & $(N=14)$ & $(N=14)$ & $(N=14)$ \\
\hline
\end{tabular}

\footnotetext{
${ }^{9}$ A two-way analysis of variance was carried out for each variable in order to exclude an effect of List (A, B), Condition (Baseline, Omitted), and an interaction between List and Condition. Number of letters: no effect of List, $F(1,52)=0.00, n s$; no effect of Condition, $F(1,52)=0.00, n s$; no interaction, $F(1,52)=0.27$, ns. Word frequency: no effect of List, $F(1,52)=0.00$, $n s$; no effect of Condition, $F(1,52)=0.00, n s$; no interaction, $F(1,52)=0.00, n s$. Number of orthographic neighbors: no effect of List, $F(1,52)=0.14, n s ;$ no effect of Condition, $F(1,52)=2.71$, ns; no interaction, $F(1,52)=0.02$, $n s$.

${ }^{10}$ The two-way analysis of variance showed no effect of lexical status, $F(1,108)=1.59$, $n s ;$ no effect of List, $F(1,108)=0.13$, $n s$, and no interaction, $F(1,108)=1.39$, ns.
} 
the accent mark in words that had one (e.g., lagrima instead of lágrima 'tear'), while we added an accent mark on the stressed syllable of the words that did not have any accent mark (e.g., nacionál instead of nacional 'national'). In the third exercise, we created nine metalinguistic questions about the accentuation rules in Spanish.

\subsubsection{Procedure}

First, the participants performed a visual go/no-go lexical decision in DMDX software (Forster, 2015). Contrary to Experiment 1, a go/no-go instead of a yes/no lexical decision task was chosen in order to facilitate the participants' task (Perea, Rosa, \& Gómez, 2002), since we observed in Experiment 1 that the task was not easy for the participants. On each trial, an asterisk appeared on the computer screen replaced after $500 \mathrm{~ms}$ by a letter string. The participants were instructed to respond as quickly as possible when a word was presented by pressing the key 'Sí' on a response box and to withhold any response when the stimulus was not a word. The participants had 2 seconds to answer and after $500 \mathrm{~ms}$ the next trial was presented. The experiment was divided into two blocks: a block for the Baseline Condition (i.e., where the stimuli appeared with accent mark; e.g., lápiz) and a block for the Omitted Condition (i.e., where the stimuli appeared without accent mark; e.g., ar$b o l)$. The presentation order (Baseline and Omitted) was counterbalanced across participants. In the block where the stimuli were presented without accent mark, the participants were told to ignore the absence of the accent mark in their decision about the stimulus being a word or not. For example, the letter string arbol had to be considered as a word despite the absence of the accent mark on $a$. The lexical decision task lasted about five minutes.

Secondly, the participants performed the evaluation of their knowledge of the written accent marks in Spanish. In the first exercise, we presented the words without the accent mark and they were instructed to place it when needed. In the second exercise, we presented the words with the wrong accentuation and the participants had to correct the accentuation (i.e., remove the accent mark or add it). In the third exercise, the participants had to answer to questions about the accentuation rules in Spanish. The whole experiment was run in a quiet room in the Universitat Autònoma de Barcelona or in the Universitat Pompeu Fabra de Barcelona.

\subsubsection{Data analysis}

Regarding the knowledge concerning the use of the written accent marks in Spanish, we corrected the three exercises and calculated a percent of correct responses for each participant.

As far as the lexical decision task was concerned, the error rates were not further analyzed since they were very low $($ mean $=5.14 \%$; range: $1.79 \%-10.71 \%)$. Only the RTs for the correct responses on the words were analyzed (i.e., the participant did not respond for the pseudowords).

We performed the same statistical analyses (i.e., on the RTs of the correct responses) as in Experiment 1. One predictor (i.e., Condition: Baseline and Omitted) and the following control variables were entered into the model: list (A, B), block order (Baseline-Omitted, Omitted-Baseline $)^{11}$, number of letters in the word ( 5 and 6 letters, considered as a nominal variable), word frequency $(\log 10$ transformed and centered on the mean), and number of the word orthographic neighbors (centered on the mean).

\subsection{Results}

\subsubsection{Knowledge concerning the use of the written accent marks in Spanish}

Regarding the evaluation of the knowledge concerning the use of the written accent marks in Spanish, results showed a mean performance of $98 \%$ of correct responses (range: 90\%-100\%). This indicates that all participants mastered the use of the written accent marks in Spanish, which allows us to rule out the possibility that the participants' orthographic skills interfere in the results.

\subsubsection{Effect of the omission of the accent mark on the visual word recognition}

The results of the final model are presented in Table $7^{12}$. As for the control variables, we only observe an effect of word frequency: the higher the word frequency, the faster the RTs.

Moreover, results show no effect of condition. As can been seen in Figure 3, the difference between Baseline (i.e., correctly spelled; $659 \mathrm{~ms}$ ) and Omitted (649 ms) is not significant.

\subsection{Discussion}

First, all participants presented a high performance in the orthographic evaluation (between $90 \%$ and $100 \%$ of correct responses), which excludes the possibility that the participants' knowledge of the written accent rules interfered in the results.

\footnotetext{
${ }^{11}$ Since the experiment was very short, the introduction of presentation order as a control variable, besides the introduction of block order, was redundant. As a consequence, the presentation order was not entered into the model.

${ }^{12}$ Given that the examination of the assumption of the normality of residuals and random effects revealed the presence of one outlier among the items (i.e., púgil 'boxer'), we also ran the analysis without it. The results with the exclusion of this item were similar to the results presented in Table 7.
} 
Table 7. Summary of the mixed-effects regression model for reaction times in Experiment 2.

\begin{tabular}{lccccc}
\hline \multicolumn{1}{c}{ Variable } & $\boldsymbol{\beta}$ & SE & $\mathbf{t}$ & $(\boldsymbol{d f f} \mathbf{F}$ & $\begin{array}{c}\boldsymbol{p} \text {-values } \\
\text { (F-tests) }\end{array}$ \\
\hline Word frequency & -0.09766 & 0.01407 & -6.94 & $(1,44)=48.20$ & $p<.001$ \\
Condition & 0.00195 & 0.01029 & 0.19 & $(1,42)=0.04$ & $\mathrm{~ns}$ \\
\hline
\end{tabular}

Figure 3. Reaction times (ms) as a function of the condition (Baseline and Omitted). The error bars are standard errors of the mean.

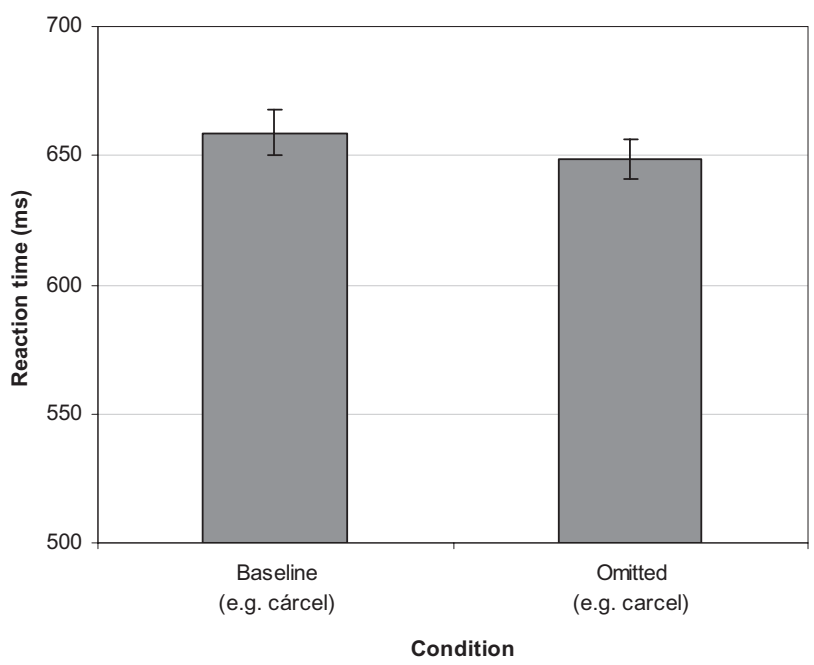

Secondly, the results of this experiment-with a simpler and more controlled experimental design than in Experiment 1 - show shorter RTs $(654 \mathrm{~ms}$ average across conditions) than in Experiment 1 ( $802 \mathrm{~ms}$ average across conditions). The similarity between the RTs in Experiment 2 and those reported in Mathey and Zagar (2006) for a similar task in French seems to indicate that the difference between Experiment 1 and 2 is more due to the easier task in Experiment 2 than to the fact that different participants took part in Experiments 1 and 2 (i.e., group difference).

Thirdly, and more interestingly, the results showed no difference between the Baseline (e.g., cárcel) and Omitted (carcel) words, which confirms, with a different experimental design, the absence of difference observed in Experiment 1 between the Baseline and Omitted conditions. Therefore, we can conclude that the omission of the accent mark does not slow down the visual word recognition.

\section{GENERAL DISCUSSION}

This research aimed at determining to what extent an orthographic error related to the accent mark hampers the visual recognition of the words. For this, we conducted two experiments of visual lexical decision (with no word production). Taken together, the results of Experiments 1 and 2 showed that the addition and/or the misplacement of an accent mark significantly slow down the visual recognition of the words, whereas the omission of the accent mark does not.

The interpretation of our results within the framework of the dual-route model is the following. According to the lexical route hypothesis (i.e., direct access from the orthographic code to the lexical representations), our results in Experiment 1 suggest that, since a processing cost was found in Added and Misplaced stimuli in comparison to Baseline stimuli, lexical access is influenced by the presence of the accent mark (see Cubelli \& Beschin, 2005, for a similar conclusion). Indeed, the accent mark acts as an orthographic cue and activates in the lexicon all words with an accent mark on the same letter. For example, the accent mark in the Added stimulus comer entails the activation of words such as cómic 'comic', which slows down the recognition of cómer as an existing word.

However, for the Omitted stimuli (in Experiments 1 and 2), the fact that the absence of the accent mark does not trigger a processing cost in comparison with the Baseline stimuli could indicate, still from the perspective of a lexical route, that the letter without the accent mark (e.g., $a$ in lapiz) constitutes a variant of the letter with the accent mark (á in lápiz; see Ayçiçeği \& Harris, 2002, for a similar conclusion in Turkish). In that sense, the Omitted stimulus lapiz would activate words such as labio 'lip' as well as words such as lápiz or láser 'laser'. Moreover, the fact that most of the words in the Omitted condition had no orthographic neighbor with a higher frequency than the one of the correctly spelled word (i.e., with the accent mark) explained why the omission of the accent mark shows no processing cost. Indeed, when the Omitted stimulus lapiz is presented, lápiz appears among the activated candidates as the neighbor with the highest frequency. This hypothesis is supported by the results reported by Zagar and Mathey (2000). In their study, when the words had no neighbor with a higher frequency, they did not find any difference in RTs between French words presented in lower-case letter (with accent mark) and words presented in capital letters (without accent mark).

The interpretation of the results from the perspective of the nonlexical route hypothesis with phonological coding and stress assignment (i.e., assuming that not only the former, but also the latter takes place even in a lexical decision task with no word production; see, for example, Ashby \& Clifton, 2005) is less straightforward. 
First, regarding the words originally without accent mark (OrNA), since the stimuli in the Added condition (e.g., dúlce) and in the Baseline condition (dulce) shared the same segmental and suprasegmental information, no processing cost should be noted (as in Gutiérrez Palma \& Palma Reyes, 2008, with a SOA of $143 \mathrm{~ms}$ ). Nevertheless, as previously stated, a processing cost was observed for the Added condition. Secondly, given that the stimuli in the Misplaced condition (e.g., dulcé) and in the Baseline condition (e.g., dulce) shared the same segmental information but not the suprasegmental information, a processing cost should be observed (again, as in Gutiérrez Palma \& Palma Reyes, 2008, with a SOA of $143 \mathrm{~ms}$ ), which was indeed the case. Thirdly, as far as the words originally with accent mark (OrWA) are concerned, since the Omitted stimuli (e.g., lapiz) as well as the Misplaced stimuli (lapiz) share the same segmental information but not the same suprasegmental information that the Baseline stimuli (lápiz), a processing cost should be observed in both conditions. However, the results showed a processing cost only for the Misplaced condition. Here again, the fact that the most frequent neighbor of the Omitted stimuli (lapiz) was the correctly spelled word (lápiz) could explain that the conflicting suprasegmental information had no significant effect on the visual recognition of the words. This finding suggests that segmental cues play a greater role than stress cues in the nonlexical route.

Moreover, still within the framework of the nonlexical route, it has not been established whether letters with and without accent mark (e.g., $u$ versus $u$ ) are processed in a similar way during the grapheme-phoneme conversion in Spanish. For that reason, we cannot rule out the possibility that the interferences observed in the Added condition (in OrNA words) and in the Misplaced condition (in OrNA and OrWA words) were caused in the graphemephoneme conversion.

Different results may be found with a task involving the production of the words. To test this, an experiment should be conducted in which participants read aloud the words and the pseudowords of Experiments 1 and 2. Not only should the time the participants need to produce the words be analyzed, but also the actual pronunciation of the words (i.e., which syllable of the words the participants actually stress). For example, it would be interesting to determine whether the participants produce the Omitted stimuli such as carcel as oxytone (i.e., as stipulated by the Spanish accentuation rules) or as paroxytone (i.e., as encoded in the lexicon).

Furthermore, a deeper examination of the use of the lexical and nonlexical routes in the visual recognition of words with an accent mark should compare the present results obtained in a transparent language (i.e., Spanish) with data collected in an opaque language, such as French. Although French accent marks are not related to lexical stress, but to vowel quality ${ }^{13}$, it would be of great interest to examine whether French-speaking participants recognize in the same way unambiguous words such as spécial 'special') written with and without the accent mark (i.e., spécial versus special) or words such as effac$e r$ 'delete', also written with and without an accent mark (i.e., éffacer versus effacer).

Finally, an important comment needs to be made about the words used in Experiments 1 and 2, which might contribute to understand the reason why no difference was found between Baseline (e.g., cárcel) and Omitted stimuli (carcel). All the words were unambiguous in the sense that they did not form part of minimal pairs such as valido-validó. However, we find a very large number of these minimal pairs in Spanish. For example, the presence of the accent mark distinguishes the first person of the present tense (e.g., tomo 'I take') from the third person of the past tense (e.g., tomó 'he took'). Thus, the accent mark is a crucial cue in the Spanish morphology. For this reason, it would be useful to examine to what extent the results obtained in the present study with unambiguous words hold with (more) ambiguous words.

In conclusion, this research, which dealt with unambiguous words that had no orthographic neighbor with a higher frequency, revealed that the addition and/or the misplacement of an accent mark significantly slow down the visual recognition of the words. On the contrary, the omission of the accent mark does not hamper the recognition of the words. These findings indicate that unambiguous words such as cárcel, lápiz or árbol 'tree' present a spelling variant without the accent mark (carcel, lapiz, arbol) that is equally processed by the readers as the variant with the accent mark. In other words, the presence of the accent mark in these kind of words is not necessary for the words to be identified, which casts some doubts about the necessity to use in the Spanish spelling the accent mark in unambiguous words.

\section{ACKNOWLEDGMENTS}

We would like to thank Diego de León Rodríguez, Olga Soler, Lorraine Baqué, M. ${ }^{a}$ Ángeles Barquero, Mario Carranza and Joaquim Llisterri for their helpful comments on an earlier version of this manuscript. Thanks also to Alain Thériault for the proofreading of this paper. This research was supported by an Ambizione grant awarded by the Swiss National Science Foundation (PZ00P1_148036).

\footnotetext{
${ }^{13}$ For example, acute and grave accent marks designate closed and open "e" vowels, respectively; e.g., prés /pвe/ 'meadows' versus près /рье/ 'close to'.
} 


\section{REFERENCES}

Alameda, J. R., \& Cuetos, F. (1995). Diccionario de frecuencias de las unidades lingüísticas del castellano. Oviedo: Servicio de Publicaciones de la Universidad de Oviedo.

Ashby, J., \& Clifton, C. (2005). The prosodic property of lexical stress affects eye movements during silent reading. Cognition, 96(3), B89-B100. http://dx.doi.org/10.1016/j.cognition.2004.12.006

Ayçiçeği, A., \& Harris, C. L. (2002). How are letters containing diacritics represented? Repetition blindness for Turkish words. European Journal of Cognitive Psychology, 14(3), 371-382. http://dx.doi.org/10.1080/09541440143000113

Baayen, H. (2008). Analyzing linguistic data. A practical introduction to statistics using $R$. Cambridge, UK: Cambridge University Press. http://dx.doi.org/10.1017/CBO9780511801686

Baayen, R. H., Davidson, D. J., \& Bates, D. M. (2008). Mixed-effects modeling with crossed random effects for subjects and items. Journal of Memory and Language, 59(4), 390-412. http://dx.doi.org/10.1016/j.jml.2007.12.005

Colombo, L. (1992). Lexical stress effect and its interaction with frequency in word pronunciation. Journal of Experimental Psychology: Human Perception and Performance, 18, 987-1003. http://dx.doi.org/10.1037/0096-1523.18.4.987

Colombo, L., Deguchi, C., \& Boureux, M. (2014). Stress priming and statistical learning in Italian nonword reading: Evidence from children. Reading and Writing, 27, 923-943. http://dx.doi. org/10.1007/s11145-013-9476-x

Colombo, L., \& Zevin, J. (2009). Stress priming in reading and the selective modulation of lexical and sub-lexical pathways. PLoS ONE, 4(9), e7219. http://dx.doi.org/10.1371/journal.pone.0007219

Coltheart, M., Rastle, K., Perry, C., Langdon, R., \& Ziegler, J. (2001). DRC: A Dual Route Cascaded model of visual word recognition and reading aloud. Psychological Review, 108, 204-256. http://dx.doi.org/10.1037/0033-295X.108.1.204

Cubelli R., \& Beschin, N. (2005). The processing of the right-sided accent mark in left neglect dyslexia. Brain and Language, 95(2), 319-326. http://dx.doi.org/10.1016/j.bandl.2005.02.002

Domínguez, A., \& Cuetos, F. (2001). Lexical stress in visual word recognition: Contrastive value in Spanish. Unpublished manuscript, Departamento de Psicología Cognitiva, University of La Laguna.

Eisenstein, J. (2013). What to do about bad language on the internet. Proceedings of the Annual Conference of the North American Chapter of the Association for Computational Linguistics. Human Language Technologies (NAACL-HLT 2013), 359-369. http://www.aclweb.org/anthology/N13-1037

Ferrand, L. (2001). Cognition et Lecture. Processus de base de la reconnaissance des mots écrits chez l'adulte. Bruxelles: De Boeck Université. http://dx.doi.org/10.3917/dbu.ferra.2001.01

Forster, J. C. (2015). DMDX updates page [Website]. Department of Psychology, University of Arizona. Retrieved from http:// www.u.arizona.edu/ jforster/dmdx.htm

Frost, R. \& Katz, L. (1992). Orthography, phonology, morphology, and meaning. Amsterdam: Elsevier North Holland Press.

González-Nosti, M., Barbón, A., Rodríguez-Ferreiro, J., \& Cuetos, F. (2014). Effects of the psycholinguistic variables on the lexical decision task in Spanish: A study with 2,765 words. Behavior Research Methods, 46(2), 517-525. http://dx.doi.org/ 10.3758/s13428-013-0383-5

Gross, J., Millett, A. L., Bartek, B., Bredell, K. H., \& Winegard, B. (2013). Evidence for prosody in silent reading. Reading Research Quarterly, 49(2), 189-208. http://dx.doi.org/10.1002/rrq.67

Guasch, M., Boada, R., Ferré, P., \& Sánchez-Casas, R. (2013). NIM: A Web-based Swiss army knife to select stimuli for psycholinguistic studies. Behavior Research Methods, 45, 765771. http://dx.doi.org/10.3758/s13428-012-0296-8

Gutiérrez Palma, N., \& Palma Reyes, A. (2004). Lexical stress and reading: A study with children. Electronic Journal of Research in Educational Psychology, 2(2), 143-160.

Gutiérrez Palma, N., \& Palma Reyes, A. (2008). On the use of lexical stress in reading Spanish. Reading and Writing, 21, 645660. http://dx.doi.org/10.1007/s11145-007-9082-x
Jara Murillo, C. V. (2013). COCAE: Corpus Cacográfico Adulto del Español de Costa Rica (Informe parcial 30/09/2013, Proyecto n. ${ }^{\circ}$ 745-B2-A13). Universidad de Costa Rica. http://hdl.handle. net $/ 10669 / 8928$

Keeulers, E., \& Brysbaert, M. (2010). Wuggy: A multilingual pseudoword generator. Behavior Research Methods, 42(3), $627-$ 633. http://dx.doi.org/10.3758/BRM.42.3.627

Kuznetsova, A., Brockhoff, P. B., \& Christensen, R. H. B. (2014). lmerTest: Tests in Linear Mixed Effects Models (v. 2.0-20) [R package]. Retrieved from http://CRAN.R-project.org/package= lmerTest

Marian, V., Bartolotti, J., Chabal, S., \& Shook, A. (2012). CLEARPOND: Cross-Linguistic Easy-Access Resource for Phonological and Orthographic Neighborhood Densities. PLOS ONE, 7(8), e43230. http://dx.doi.org/10.1371/journal.pone.0043230

Martín Plasencia, P., Iglesias Dorado J., \& Serrano, J. M. (2008). Evidence for linguistic deficit in nonlexical processing in reading. A study of a Spanish-speaking patient. The Spanish Journal of Psychology, 11, 48-54. http://dx.doi.org/10.1017/S11387416 00004108

Mathey, S., \& Zagar, D. (2006). The orthographic neighbourhood frequency effect in French: A letter-case manipulation study. Canadian Journal of Experimental Psychology, 60(2), 159165. http://dx.doi.org/10.1037/cjep2006015

Morton, J. (1969). Interaction of information in word recognition. Psychological Review, 76(2), 165-178. http://dx.doi.org/10. 1037/h0027366

Pagliuca, G., \& Monaghan, P. (2010). Discovering large grain-sizes in a transparent orthography: Insights from a connectionist model of Italian word naming. European Journal of Cognitive Psychology, 22,813-835. http://dx.doi.org/10.1080/09541440903172158

Perea, M., Rosa, E., \& Gómez, C. (2002). Is the go/no-go lexical decision task an alternative to the yes/no lexical decision task? Memory \& Cognition, 30, 34-45. http://dx.doi.org/10.3758/ BF03195263

Pérez, M. A., Alameda, J. R., \& Cuetos Vega, F. (2003). Frecuencia, longitud y vecindad ortográfica de las palabras de 3 a 16 letras del Diccionario de la Lengua Española (RAE, 1992). Revista Electrónica de Metodología Aplicada, 8(2), 1-10.

Perry, C., Ziegler, J. C., \& Zorzi, M. (2010). Beyond single syllables: Large-scale modeling of reading aloud with the Connectionist Dual Process (CDP++) model. Cognitive Psychology, 61(2), 106-151. http://dx.doi.org/10.1016/j.cogpsych.2010.04.001

Perry, C., Ziegler, J. C., \& Zorzi, M. (2014). CDP++. Italian: Modelling sublexical and supralexical inconsistency in a shallow orthography. Plos One, 9(4), e94291. http://dx.doi.org/10.1371/ journal.pone.0094291

Protopapas, A. (in press). From diacritics to the mental lexicon: Where is the stress? In J. Thomson \& L. Jarmulowicz (Eds.), Linguistic rhythm and literacy. John Benjamins. Retrieved from http://users.uoa.gr/ aprotopapas/CV/pdf/Protopapas_TiLARch14 draft2.pdf

Protopapas, A., \& Gerakaki, S. (2009). Development of processing stress diacritics in reading Greek. Scientific Studies of Reading, 13, 453-483. http://dx.doi.org/10.1080/10888430903034788

Protopapas, A., Gerakaki, S., \& Stella, A. (2007). Sources of information for stress assignment in reading Greek. Applied Psycholinguistics, 28, 695-720. http://dx.doi.org/10.1017/S0142716407070373

Pujol, M. (2005). La ortografía. In S. Torner \& P. Battaner (Eds.), El corpus PAAU 1992: Estudios descriptivos, textos y vocabulario (pp. 29-65). Barcelona: Universitat Pompeu Fabra.

Quilis, A. (1981). Fonética acústica de la lengua española. Madrid: Gredos.

Quilis, A. (1993). Tratado de fonología y fonética españolas. Madrid: Gredos.

Rastle, K., \& Coltheart, M. (2000). Lexical and nonlexical print-tosound translation of disyllabic words and nonwords. Journal of Memory and Language, 42, 342-364. http://dx.doi.org/10.1006/ jmla.1999.2687

Real Academia Española y Asociación de Academias de la Lengua Española (2005). Diccionario panhispánico de dudas. Madrid: Santillana. 
Seidenberg, M. S., \& McClelland, J. L. (1989). A distributed, developmental model of word recognition and naming. Psychological Review, 96(4), 523-568. http://dx.doi.org/10.1037/0033295X.96.4.523

Ševa, N., Monaghan, P., \& Arciuli, J. (2009). Stressing what is important: Orthographic cues and lexical stress assignment. Journal of Neurolinguistics, 22, 237-249. http://dx.doi.org/10.1016/ j.jneuroling.2008.09.002

Soto-Faraco, S., Sebastián-Gallés, N., \& Cutler, A. (2001). Segmental and suprasegmental mismatch in lexical access. Journal of Memory and Language, 45, 412-432. http://dx.doi.org/10.1006/ jmla.2000.2783

The English Spelling Society (2010). The changing face of spelling on the internet. A research document drawn from research at Manchester University. Research notes and diagrams cour- tesy of Lucy Jones. http://pdf.thepdfportal.net/PDFFiles/ 129174.pdf

van Orden, G. C. (1987). A ROWS is a ROSE: Spelling, sound, and reading. Memory \& Cognition, 15, 181-198. http://dx.doi.org/ 10.3758/BF03197716

Zagar, D., \& Mathey, S. (2000). When words with higher-frequency neighbours become words with no higher-frequency neighbours (or how to undress the neighbourhood frequency effect). In A. Kennedy, R. Radach, D. Heller, \& J. Pynte (Eds.), Reading as a perceptual process (pp. 23-46). Oxford: Elsevier. http://dx.doi.org/10.1016/B978-008043642-5/50004-8

Ziegler, J. C., Perry, C., \& Coltheart, M. (2000). The DRC model of visual word recognition and reading aloud: An extension to German. European Journal of Cognitive Psychology, 12, 413430. http://dx.doi.org/10.1080/09541440050114570

\section{APPENDIX A. WORDS AND PSEUDOWORDS IN EXPERIMENT 1}

\section{A1. Words}

\begin{tabular}{|c|c|c|c|c|c|}
\hline Word & $\begin{array}{c}\text { Number of } \\
\text { letters }\end{array}$ & $\begin{array}{c}\text { Frequency } \\
\text { (Alameda \& } \\
\text { Cuetos, 1995) }\end{array}$ & $\begin{array}{c}\text { Nr. of orthogr. } \\
\text { neighbors } \\
\text { (Pérez et al., 2003) }\end{array}$ & $\begin{array}{l}\text { Nr. of orthogr. neighbors } \\
\text { with higher frequency } \\
\text { (Pérez et al., 2003) }\end{array}$ & $\begin{array}{l}\text { Cumulative frequency of } \\
\text { the orthogr. neighbors } \\
\text { (Pérez et al., 2003) }\end{array}$ \\
\hline \multicolumn{6}{|c|}{ OXYTONE WORDS WITHOUT ACCENT MARK (OrNA) } \\
\hline cantar & 6 & 36.5 & 11 & 1 & 91 \\
\hline civil & 5 & 76.5 & 1 & 0 & 0 \\
\hline comer & 5 & 110.5 & 4 & 0 & 30.5 \\
\hline fatal & 5 & 29.5 & 3 & 0 & 12 \\
\hline feliz & 5 & 99 & 1 & 0 & 0 \\
\hline feroz & 5 & 16 & 1 & 0 & 0.5 \\
\hline fugaz & 5 & 16.5 & 1 & 0 & 0 \\
\hline nariz & 5 & 70.5 & 2 & 0 & 3.5 \\
\hline nivel & 5 & 97.5 & 1 & 0 & 0 \\
\hline olor & 4 & 122 & 3 & 0 & 67.5 \\
\hline perfil & 6 & 43 & 1 & 0 & 0 \\
\hline senil & 5 & 2 & 2 & 0 & 0.5 \\
\hline temor & 5 & 55.5 & 3 & 0 & 28.5 \\
\hline valor & 5 & 142.5 & 5 & 0 & 151 \\
\hline veraz & 5 & 6 & 3 & 2 & 37.5 \\
\hline \multicolumn{6}{|c|}{ PAROXYTONE WORDS WITHOUT ACCENT MARK (OrNA) } \\
\hline barco & 5 & 52 & 11 & 1 & 144.5 \\
\hline besos & 4 & 38 & 12 & 1 & 99 \\
\hline burla & 5 & 14.5 & 6 & 0 & 8.5 \\
\hline canon & 5 & 4 & 1 & 0 & 2.5 \\
\hline cumbre & 6 & 7.5 & 2 & 0 & 7 \\
\hline diablo & 6 & 31 & 1 & 0 & 1 \\
\hline dulce & 5 & 52 & 0 & 0 & 0 \\
\hline foto & 4 & 38 & 20 & 1 & 108 \\
\hline golpe & 5 & 89 & 2 & 0 & 0 \\
\hline gorras & 6 & 13 & 13 & 1 & 52.5 \\
\hline joven & 5 & 215 & 0 & 0 & 0 \\
\hline loza & 4 & 1.5 & 13 & 8 & 66 \\
\hline lunes & 5 & 31.5 & 1 & 0 & 0 \\
\hline orden & 5 & 228 & 0 & 0 & 0 \\
\hline silla & 5 & 66 & 12 & 0 & 32 \\
\hline
\end{tabular}




\begin{tabular}{|c|c|c|c|c|c|}
\hline Word & $\begin{array}{l}\text { Number of } \\
\text { letters }\end{array}$ & $\begin{array}{c}\text { Frequency } \\
\text { (Alameda \& } \\
\text { Cuetos, 1995) }\end{array}$ & $\begin{array}{c}\text { Nr. of orthogr. } \\
\text { neighbors } \\
\text { (Pérez et al., 2003) }\end{array}$ & $\begin{array}{l}\text { Nr. of orthogr. neighbors } \\
\text { with higher frequency } \\
\text { (Pérez et al., 2003) }\end{array}$ & $\begin{array}{l}\text { Cumulative frequency of } \\
\text { the orthogr. neighbors } \\
\text { (Pérez et al., 2003) }\end{array}$ \\
\hline \multicolumn{6}{|c|}{ OXYTONE WORDS WITH ACCENT MARK (OrWA) } \\
\hline adiós & 5 & 26.5 & 0 & 0 & 0 \\
\hline anis & 4 & 4.5 & 0 & 0 & 0 \\
\hline avión & 5 & 40.5 & 2 & 0 & 4 \\
\hline bambú & 5 & 8.5 & 1 & 0 & 0 \\
\hline café & 4 & 105 & 2 & 0 & 0.5 \\
\hline compás & 6 & 15 & 0 & 0 & 0 \\
\hline común & 5 & 158 & 0 & 0 & 0 \\
\hline inglés & 6 & 76 & 0 & 0 & 0 \\
\hline jamás & 5 & 173.5 & 0 & 0 & 0 \\
\hline menú & 4 & 3.5 & 1 & 0 & 1.5 \\
\hline pasión & 6 & 66 & 5 & 0 & 1 \\
\hline sartén & 6 & 4 & 0 & 0 & 0 \\
\hline sofá & 4 & 33.5 & 1 & 0 & 0 \\
\hline tabú & 4 & 4 & 5 & 0 & 1 \\
\hline unión & 5 & 50 & 1 & 0 & 4 \\
\hline \multicolumn{6}{|c|}{ PAROXYTONE WORDS WITH ACCENT MARK (OrWA) } \\
\hline álbum & 5 & 4 & 0 & 0 & 0 \\
\hline ámbar & 5 & 10.5 & 0 & 0 & 0 \\
\hline ángel & 5 & 25 & 0 & 0 & 0 \\
\hline árbol & 5 & 55 & 1 & 0 & 0 \\
\hline cáncer & 6 & 24 & 1 & 0 & 0 \\
\hline cárcel & 6 & 31 & 2 & 0 & 2.5 \\
\hline césped & 6 & 6 & 1 & 0 & 0 \\
\hline débil & 5 & 34 & 0 & 0 & 0 \\
\hline fácil & 5 & 140.5 & 0 & 0 & 0 \\
\hline frágil & 6 & 22 & 0 & 0 & 0 \\
\hline fútbol & 6 & 31 & 1 & 0 & 0 \\
\hline lápiz & 5 & 10 & 0 & 0 & 0 \\
\hline mármol & 6 & 47 & 1 & 0 & 0 \\
\hline mártir & 6 & 8 & 0 & 0 & 0 \\
\hline útil & 4 & 32.5 & 0 & 0 & 0 \\
\hline
\end{tabular}


A2. Pseudowords

\begin{tabular}{|c|c|c|c|c|c|c|c|}
\hline \multicolumn{2}{|c|}{$\begin{array}{c}\text { OXYTONE } \\
\text { PSEUDOWORDS WITH } \\
\text { ACCENT MARK }\end{array}$} & \multicolumn{2}{|c|}{$\begin{array}{c}\text { PAROXYTONE } \\
\text { PSEUDOWORDS WITH } \\
\text { ACCENT MARK }\end{array}$} & \multicolumn{2}{|c|}{$\begin{array}{c}\text { OXYTONE } \\
\text { PSEUDOWORDS } \\
\text { WITHOUT ACCENT MARK } \\
\end{array}$} & \multicolumn{2}{|c|}{$\begin{array}{c}\text { PAROXYTONE } \\
\text { PSEUDOWORDS } \\
\text { WITHOUT ACCENT MARK } \\
\end{array}$} \\
\hline Pseudowords & $\begin{array}{l}\text { Number } \\
\text { of letters }\end{array}$ & Pseudowords & $\begin{array}{l}\text { Number } \\
\text { of letters }\end{array}$ & Pseudowords & $\begin{array}{l}\text { Number } \\
\text { of letters }\end{array}$ & Pseudowords & $\begin{array}{l}\text { Number } \\
\text { of letters }\end{array}$ \\
\hline ariós & 5 & ámpar & 5 & canter & 6 & barla & 5 \\
\hline avián & 5 & ántel & 5 & cavil & 5 & barto & 5 \\
\hline bamcú & 5 & árbel & 5 & cober & 5 & begos & 5 \\
\hline cadé & 4 & cárpel & 6 & faroz & 5 & canen & 5 \\
\hline camún & 5 & césted & 6 & fasal & 5 & cumbra & 6 \\
\hline compis & 6 & cúncer & 6 & felez & 5 & diaclo & 6 \\
\hline inclés & 6 & dábil & 5 & futaz & 5 & dulpe & 5 \\
\hline inión & 5 & fácel & 5 & namiz & 5 & futo & 4 \\
\hline inis & 4 & frúgil & 6 & navel & 5 & golte & 5 \\
\hline janás & 5 & fúsbol & 6 & olir & 4 & govas & 5 \\
\hline monú & 4 & lámiz & 5 & permil & 6 & javen & 5 \\
\hline pasián & 6 & mártor & 6 & sedil & 5 & lozu & 4 \\
\hline sarfén & 6 & múrmol & 6 & tamor & 5 & lufes & 5 \\
\hline sová & 4 & ólbum & 5 & valur & 5 & ormen & 5 \\
\hline tabé & 4 & úpil & 4 & $v e f a z$ & 5 & sillo & 5 \\
\hline
\end{tabular}


APPENDIX B. WORDS AND PSEUDOWORDS IN EXPERIMENT 2

\section{B1. List A}

B1.1. Words

\begin{tabular}{|c|c|c|c|c|c|c|c|}
\hline \multicolumn{8}{|c|}{ LIST A } \\
\hline $\begin{array}{l}\text { Lexical } \\
\text { status }\end{array}$ & Condition & Stimulus & $\begin{array}{l}\text { Gramm. } \\
\text { category }\end{array}$ & $\begin{array}{l}\text { Nr. } \\
\text { letters }\end{array}$ & $\begin{array}{c}\text { Frequency } \\
\text { (Guasch et al., } \\
\text { 2013) }\end{array}$ & $\begin{array}{c}\text { Nr. orthogr. } \\
\text { neighbors } \\
\text { (Guasch et al., } \\
\text { 2013) }\end{array}$ & $\begin{array}{l}\text { Bigram frequency } \\
\text { (Marian et al., } \\
\text { 2012) }\end{array}$ \\
\hline Word & With & ángel & noun & 5 & 17.6 & 0 & 0.0111 \\
\hline Word & With & cáliz & noun & 5 & 2.8 & 1 & 0.0116 \\
\hline Word & With & cárcel & noun & 6 & 51.2 & 3 & 0.019 \\
\hline Word & With & cónsul & noun & 6 & 8.9 & 0 & 0.0181 \\
\hline Word & With & cráter & noun & 6 & 1.4 & 0 & 0.0483 \\
\hline Word & With & dátil & noun & 5 & 0.2 & 0 & 0.017 \\
\hline Word & With & débil & noun, adj & 5 & 32.3 & 0 & 0.0136 \\
\hline Word & With & dócil & adj & 5 & 6.6 & 0 & 0.0182 \\
\hline Word & With & fácil & adj & 5 & 121.2 & 0 & 0.0187 \\
\hline Word & With & mástil & noun & 6 & 3.4 & 0 & 0.0435 \\
\hline Word & With & néctar & noun & 6 & 1.6 & 0 & 0.0697 \\
\hline Word & With & púgil & noun & 5 & 0.5 & 0 & 0.0106 \\
\hline Word & With & tándem & noun & 6 & 1.8 & 0 & 0.024 \\
\hline Word & With & tórax & noun & 5 & 5.9 & 1 & 0.0186 \\
\hline Word & Without & album & noun & 5 & 5.3 & 1 & 0.0142 \\
\hline Word & Without & arbol & noun & 5 & 34.8 & 2 & 0.0184 \\
\hline Word & Without & cancer & noun & 6 & 68.4 & 2 & 0.0867 \\
\hline Word & Without & cesped & noun & 6 & 13.1 & 0 & 0.0598 \\
\hline Word & Without & ductil & adj & 6 & 1.4 & 0 & 0.0292 \\
\hline Word & Without & femur & noun & 5 & 0.9 & 0 & 0.0157 \\
\hline Word & Without & fertil & noun, adj & 6 & 5.2 & 0 & 0.0567 \\
\hline Word & Without & futbol & noun & 6 & 92.6 & 0 & 0.0108 \\
\hline Word & Without & habil & adj & 5 & 8.7 & 1 & 0.0314 \\
\hline Word & Without & puber & noun & 5 & 0.5 & 3 & 0.0523 \\
\hline Word & Without & simil & noun & 5 & 2.1 & 1 & 0.0261 \\
\hline Word & Without & tactil & adj & 6 & 2.5 & 0 & 0.0355 \\
\hline Word & Without & trebol & noun & 6 & 0.4 & 0 & 0.038 \\
\hline Word & Without & tunel & noun & 5 & 15.6 & 1 & 0.0191 \\
\hline
\end{tabular}


B1.2. Pseudowords

\begin{tabular}{|c|c|c|c|c|c|c|c|}
\hline \multicolumn{8}{|c|}{ LIST A } \\
\hline $\begin{array}{c}\text { Lexical } \\
\text { status }\end{array}$ & Condition & Stimulus & $\begin{array}{l}\text { Gramm. } \\
\text { category }\end{array}$ & $\begin{array}{c}\text { Nr. } \\
\text { letters }\end{array}$ & $\begin{array}{c}\text { Frequency } \\
\text { (Guasch et al., } \\
\text { 2013) }\end{array}$ & $\begin{array}{l}\text { Nr. orthogr. } \\
\text { neighbors } \\
\text { (Guasch et al., } \\
\text { 2013) }\end{array}$ & $\begin{array}{c}\text { Bigram frequency } \\
\text { (Marian et al., } \\
\text { 2012) }\end{array}$ \\
\hline Pseudoword & With & álbel & - & 5 & - & 0 & 0.0115 \\
\hline Pseudoword & With & ásdum & - & 5 & - & 0 & 0.0035 \\
\hline Pseudoword & With & brébil & - & 6 & - & 0 & 0.0112 \\
\hline Pseudoword & With & búnil & - & 5 & - & 0 & 0.0122 \\
\hline Pseudoword & With & cálger & - & 6 & - & 0 & 0.0297 \\
\hline Pseudoword & With & cénfed & - & 6 & - & 0 & 0.0102 \\
\hline Pseudoword & With & fórdil & - & 6 & - & 0 & 0.0183 \\
\hline Pseudoword & With & fúgmol & - & 6 & - & 0 & 0.0064 \\
\hline Pseudoword & With & lébur & - & 5 & - & 0 & 0.0052 \\
\hline Pseudoword & With & léctil & - & 6 & - & 0 & 0.0228 \\
\hline Pseudoword & With & múbol & - & 5 & - & 0 & 0.0083 \\
\hline Pseudoword & With & námil & - & 5 & - & 0 & 0.0155 \\
\hline Pseudoword & With & rinil & - & 5 & - & 0 & 0.0126 \\
\hline Pseudoword & With & tírtil & - & 6 & - & 0 & 0.0307 \\
\hline Pseudoword & Without & ancil & - & 5 & - & 0 & 0.035 \\
\hline Pseudoword & Without & calsel & - & 6 & - & 0 & 0.0632 \\
\hline Pseudoword & Without & cobem & - & 5 & - & 0 & 0.0739 \\
\hline Pseudoword & Without & cormax & - & 6 & - & 0 & 0.0976 \\
\hline Pseudoword & Without & cumiz & - & 5 & - & 0 & 0.0243 \\
\hline Pseudoword & Without & depel & - & 5 & - & 0 & 0.0654 \\
\hline Pseudoword & Without & fanir & - & 5 & - & 0 & 0.0362 \\
\hline Pseudoword & Without & flader & - & 6 & - & 0 & 0.0445 \\
\hline Pseudoword & Without & gobil & - & 5 & - & 0 & 0.0207 \\
\hline Pseudoword & Without & latul & - & 5 & - & 0 & 0.0256 \\
\hline Pseudoword & Without & mestul & - & 6 & - & 0 & 0.0715 \\
\hline Pseudoword & Without & munil & - & 5 & - & 0 & 0.0229 \\
\hline Pseudoword & Without & niltar & - & 6 & - & 0 & 0 \\
\hline Pseudoword & Without & sandum & - & 6 & - & 0 & 0.0473 \\
\hline
\end{tabular}


B2. List B

B2.1. Words

\begin{tabular}{|c|c|c|c|c|c|c|c|}
\hline \multicolumn{8}{|c|}{ LIST B } \\
\hline $\begin{array}{c}\text { Lexical } \\
\text { status }\end{array}$ & Condition & Stimulus & $\begin{array}{l}\text { Gramm. } \\
\text { category }\end{array}$ & $\begin{array}{c}\text { Nr. } \\
\text { letters }\end{array}$ & $\begin{array}{c}\text { Frequency } \\
\text { (Guasch et al., } \\
\text { 2013) }\end{array}$ & $\begin{array}{c}\text { Nr. orthogr. } \\
\text { neighbors } \\
\text { (Guasch et al., } \\
\text { 2013) }\end{array}$ & $\begin{array}{c}\text { Bigram frequency } \\
\text { (Marian et al., } \\
\text { 2012) }\end{array}$ \\
\hline Word & With & álbum & noun & 5 & 5.3 & 0 & 0.0034 \\
\hline Word & With & árbol & noun & 5 & 34.8 & 0 & 0.008 \\
\hline Word & With & cáncer & noun & 6 & 68.4 & 2 & 0.0401 \\
\hline Word & With & césped & noun & 6 & 13.1 & 0 & 0.0236 \\
\hline Word & With & dúctil & adj & 6 & 1.4 & 0 & 0.0223 \\
\hline Word & With & fémur & noun & 5 & 0.9 & 0 & 0.0062 \\
\hline Word & With & fértil & noun adj & 6 & 5.2 & 0 & 0.0294 \\
\hline Word & With & fútbol & noun & 6 & 92.6 & 0 & 0.0035 \\
\hline Word & With & hábil & adj & 5 & 8.7 & 1 & 0.0136 \\
\hline Word & With & púber & noun & 5 & 0.5 & 1 & 0.0428 \\
\hline Word & With & símil & noun & 5 & 2.1 & 0 & 0.0161 \\
\hline Word & With & táctil & adj & 6 & 2.5 & 0 & 0.023 \\
\hline Word & With & trébol & noun & 6 & 0.4 & 0 & 0.0189 \\
\hline Word & With & túnel & noun & 5 & 15.6 & 2 & 0.013 \\
\hline Word & Without & angel & noun & 5 & 17.6 & 3 & 0.018 \\
\hline Word & Without & caliz & noun & 5 & 2.8 & 2 & 0.0599 \\
\hline Word & Without & carcel & noun & 6 & 51.2 & 5 & 0.0701 \\
\hline Word & Without & consul & noun & 6 & 8.9 & 0 & 0.1136 \\
\hline Word & Without & crater & noun & 6 & 1.4 & 1 & 0.0676 \\
\hline Word & Without & datil & noun & 5 & 0.2 & 0 & 0.0281 \\
\hline Word & Without & debil & noun adj & 5 & 32.3 & 1 & 0.0594 \\
\hline Word & Without & docil & adj & 5 & 6.6 & 0 & 0.0293 \\
\hline Word & Without & facil & $\operatorname{adj}$ & 5 & 121.2 & 0 & 0.0322 \\
\hline Word & Without & mastil & noun & 6 & 3.4 & 1 & 0.0747 \\
\hline Word & Without & nectar & noun & 6 & 1.6 & 0 & 0.0939 \\
\hline Word & Without & pugil & noun & 5 & 0.5 & 0 & 0.0184 \\
\hline Word & Without & tandem & noun & 6 & 1.8 & 0 & 0.0467 \\
\hline Word & Without & torax & noun & 5 & 5.9 & 0 & 0.0442 \\
\hline
\end{tabular}


B2.2. Pseudowords

\begin{tabular}{|c|c|c|c|c|c|c|c|}
\hline \multicolumn{8}{|c|}{ LIST B } \\
\hline $\begin{array}{c}\text { Lexical } \\
\text { status }\end{array}$ & Condition & Stimulus & $\begin{array}{l}\text { Gramm. } \\
\text { category }\end{array}$ & $\begin{array}{c}\text { Nr. } \\
\text { letters }\end{array}$ & $\begin{array}{c}\text { Frequency } \\
\text { (Guasch et al., } \\
\text { 2013) }\end{array}$ & $\begin{array}{c}\text { Nr. orthogr. } \\
\text { neighbors } \\
\text { (Guasch et al., } \\
\text { 2013) }\end{array}$ & $\begin{array}{l}\text { Bigram frequency } \\
\text { (Marian et al., } \\
\text { 2012) }\end{array}$ \\
\hline Pseudoword & With & áncil & - & 5 & - & 0 & 0.0281 \\
\hline Pseudoword & With & cálsel & - & 6 & - & 0 & 0.0149 \\
\hline Pseudoword & With & cóbem & - & 5 & - & 0 & 0.0099 \\
\hline Pseudoword & With & córmax & - & 6 & - & 0 & 0.0205 \\
\hline Pseudoword & With & cúmiz & - & 5 & - & 0 & 0.0094 \\
\hline Pseudoword & With & dépel & - & 5 & - & 0 & 0.0163 \\
\hline Pseudoword & With & fánir & - & 5 & - & 0 & 0.0125 \\
\hline Pseudoword & With & fláder & - & 6 & - & 0 & 0.0338 \\
\hline Pseudoword & With & góbil & - & 5 & - & 0 & 0.0123 \\
\hline Pseudoword & With & látul & - & 5 & - & 0 & 0.0105 \\
\hline Pseudoword & With & méstul & - & 6 & - & 0 & 0.0305 \\
\hline Pseudoword & With & múnil & - & 5 & - & 0 & 0.0121 \\
\hline Pseudoword & With & níltar & - & 6 & - & 0 & 0.0706 \\
\hline Pseudoword & With & sándum & - & 6 & - & 0 & 0.0171 \\
\hline Pseudoword & Without & albel & - & 5 & - & 0 & 0.0223 \\
\hline Pseudoword & Without & asdum & - & 5 & - & 0 & 0.0108 \\
\hline Pseudoword & Without & brebil & - & 6 & - & 0 & 0.0303 \\
\hline Pseudoword & Without & bunil & - & 5 & - & 0 & 0.02 \\
\hline Pseudoword & Without & calger & - & 6 & - & 0 & 0.078 \\
\hline Pseudoword & Without & cenfed & - & 6 & - & 0 & 0.0378 \\
\hline Pseudoword & Without & fordil & - & 6 & - & 0 & 0.04 \\
\hline Pseudoword & Without & fugmol & - & 6 & - & 0 & 0.0134 \\
\hline Pseudoword & Without & lebur & - & 5 & - & 0 & 0.0145 \\
\hline Pseudoword & Without & lectil & - & 6 & - & 0 & 0.0479 \\
\hline Pseudoword & Without & mubol & - & 5 & - & 0 & 0.0195 \\
\hline Pseudoword & Without & namil & - & 5 & - & 0 & 0.0266 \\
\hline Pseudoword & Without & rinil & - & 5 & - & 0 & 0.0224 \\
\hline Pseudoword & Without & tirtil & - & 6 & - & 0 & 0.0419 \\
\hline
\end{tabular}

